Vol. 2 No. 2- August 2021

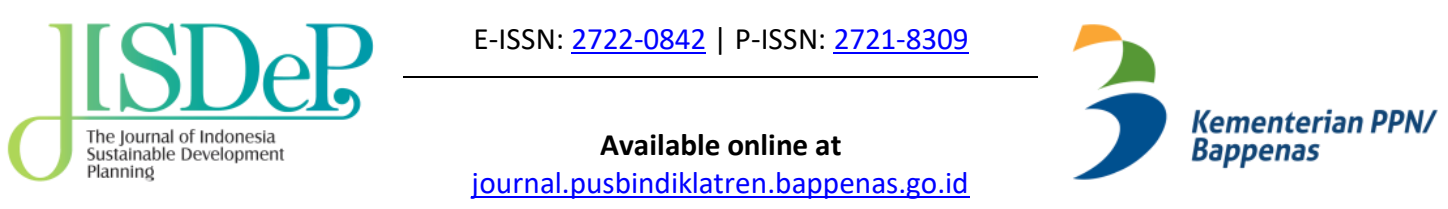

Book Review

\title{
Planning Theory: Schools of Thought and Practices of Regional Development Planning
}

\author{
Andri N.R. Mardiah ${ }^{1,2}$ \\ Ministry of National Development Planning/Bappenas ${ }^{1}$ \\ Senior Research Fellow Amcolabora Institute, Bogor, Indonesia ${ }^{2}$
}

Introduction

The book entitled, 'Teori Perencanaan: Mazhab dan Praktik Perencanaan Pengembangan Wilayah,' [in English: Planning Theory: Schools of Thought and Practices of Regional Development Planning], is written by Indonesian practitioners and researchers active in the planning field with an easyto-understand writing style. The authors, Ernan Rustiadi (IPB), Galuh Syahbana (LIPI), and Setyardi (IPB), thoroughly present the dualism of procedural and substantial planning theory, with the bulk of discussion given to the substantial domain. This book is organized into seven sections, from the introduction to the closing sections. This book discusses the schools of thought in planning theory (i.e., positivism, postpositivism, and green planning), prominent planning figures and/or thinkers, and their shifting paradigm in the planning field, completed with planning practices that intersect with the history of planning in Indonesia and abroad.

\section{Key Points and Review}

The book becomes interesting because, though in a small portion, the authors tried to put planning theories into Indonesia's dynamic context within multiple periods (colonial, the old order, new order, and post-reform) and integrate political conditions, democracy (leadership shifting) and the role of the state and market mechanisms. This book helps understand contextual planning, primarily due to the paradigm shift as the resource envelope managed directly by the state decreases. For the sake of optimization, planning and budgeting should go hand in hand under the direction of the same orchestra. However, planning has been more technocratic in practice, while budgeting has been more politically intervened. Failure to maintain such synergy can cause severe developmental problems deviated from

ARTICLE INFO

Received: August 23, 2021

Received in revised form: August 27, 2021

Accepted: August 27, 2021
JISDeP - The Journal of Indonesia Sustainable Development Planning Published by Centre for Planners' Development, Education, and Training (Pusbindiklatren),

Ministry of National Development

Planning/ National Development

Planning Agency (Bappenas), Republic of Indonesia

Address: Jalan Proklamasi 70,
Central Jakarta, Indonesia 10320
Phone: $+622131928280 / 31928285$
Fax: +622131928281
E-mail:
journal.pusbindiklatren@bappenas.go.id
Supported by Indonesian Development Planners
Association (PPPI)

Central Jakarta, Indonesia 10320

Phone: +62 21 31928280/31928285

E-mail:

Supported by Indonesian Development Planners 
the targeted impacts. Furthermore, by observing the role of planning and budgeting, future planning theories can further discuss financing innovations and alternative financing integrated into planning.

Development planning can be viewed from a cross-sectoral perspective, across regions and administrative boundaries, and across stakeholders and authorities in a cross-time frame concerning spatial planning. This book demonstrates that eventually, planning theories and social phenomena are two interrelated interactions and mutually shape one another because of 'reflection and abstraction of planning phenomena and practices.' Having reviewed planning practices in foreign countries, the authors argued that national planning in Europe and Asia is not too detailed and emphasizes planning at district or municipal levels. Europe no longer has a comprehensive development like Indonesia's RPJMN and RPJP and focuses more on strategic issues. Conversely, comprehensive planning is still observed in developing countries and Asia, such as China, Thailand, and Vietnam.

Development challenges are closely related to aspects of regional and geographical disparities. Reflecting on Indonesia's condition, where two-thirds of its territory is covered by oceans and having tens of thousands of islands, island-based planning should receive a proportionate share of discussion in addition to terrestrial-based planning. The fundamental and thought-provoking part of the book is when the authors assess planning based on environmental issues, which later become the root of the framework for sustainable development, the concept of carrying capacity, and the ecological footprint. It will be more appealing if green planning is enriched with mainstreaming disaster risk reduction, adaptation to climate change, and circular economy issues. These issues are partly the contemporary responses to the ecological footprint paradigm, conceptualized by William E. Rees ${ }^{1}$.

\section{Concluding Remark}

This book purely focuses on planning and is less concerned with planning failures occurring at the implementation level and how other scientific disciplines intertwine and influence each other at the practical level, as in sociology, to understand rapid behavioral changes in society and the key actors involved. In addition, planning politics is also a fascinating topic to be further discussed for the betterment of this book in the future. The result of technocratic and participatory processes will undergo various adjustments due to changes in the political process with its high dynamics of uncertainty and complexity. In the future, the planning - which is essentially a rational human way to deal with uncertainty- will face more challenges of the rapid and volatile change (VUCA). VUCA is an acronym for volatility, uncertainty, complexity, and ambiguity.

Finally, this 462-page book with knowledge-intensive content is very worth reading. It reminds planning activists to be able to understand planning in the contextualization of regional development and socio-spatial planning and, in the end, to restore the logic of thinking about managing limited natural resources more wisely and sustainably. This book may become an initial reading to provoke planners to return to science-based policy, where all policies are supported by a scientific basis (theory and research) and tacit knowledge from best practices verified by science.

\section{The Book Rating}

Quoting the first sentence of this book, 'in fact, humans have always lived in the face of uncertainty... uncertainty in humans creates costs, burdens and risks' (p.1), this book can serve as an enlightenment for us that to encourage economic growth and at the same time reduce uncertainty in development does not necessarily mean endangering the survival of civilization and the resilience of the

\footnotetext{
${ }^{1}$ A professor emeritus who is known for making the concept of "ecological footprint" which become the most important reference for global sustainable analysis
} 
nation. Thus, as for knowing the basic philosophy of planning for the purpose of the planning quality enhancement, this book has delivered insightful key messages and therefore, it deserves five stars rating.

\section{COVER BOOK REVIEW}

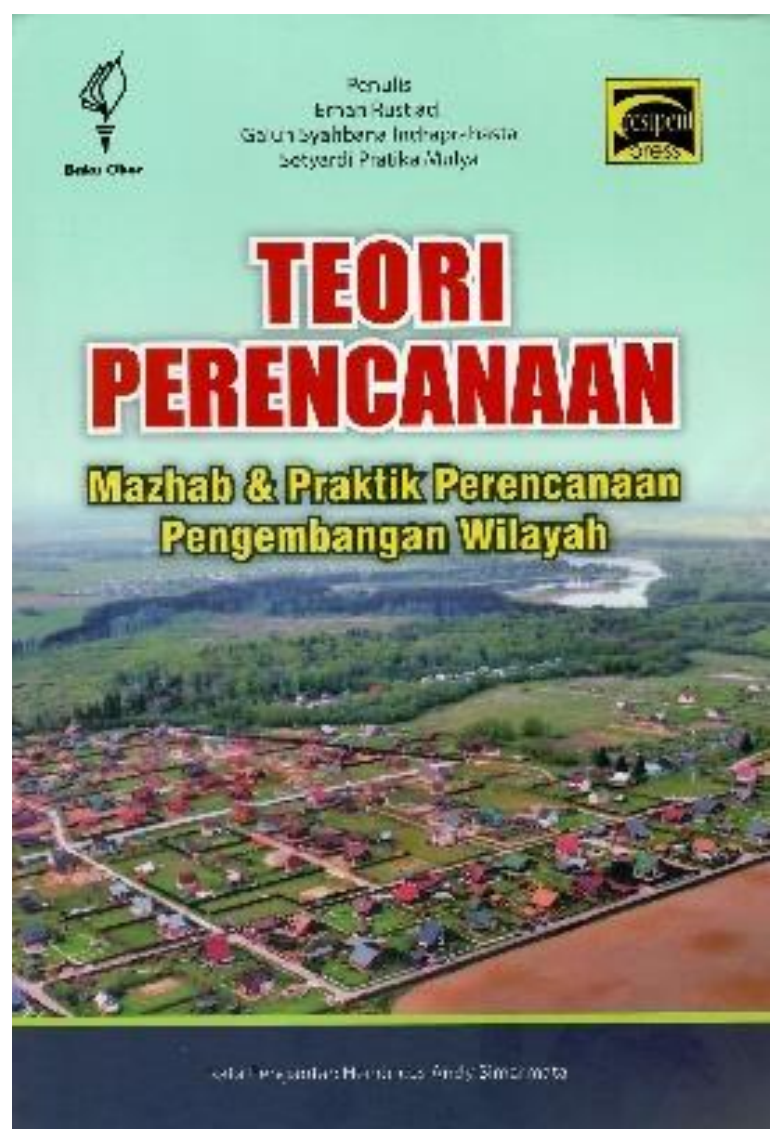

